\title{
PRURITUS AS A MARKER OF IMMUNE DISTURBANCES IN PSORIASIS
}

\author{
A.A. Barilo, S.V. Smirnova \\ Scientific Research Institute of Medical Problems of the North - Federal Research Center \\ "Krasnoyarsk Science Center" of the Siberian Branch of the Russian Academy of Sciences, Krasnoyarsk, Russia

\section{КОЖНЫЙ ЗУД КАК МАРКЕР ИММУННЫХ НАРУШЕНИЙ У БОЛЬНЫХ ПСОРИАЗОМ}

\author{
А.А. Барило, С.В. Смирнова \\ Научно-исследовательский институт медицинских проблем Севера - обособленное подразделение \\ ФГБНУ «Федеральный исследовательский центр „Красноярский научный центр” \\ Сибирского отделения РАН», Красноярск
}

anntomsk@yandex.ru

\begin{abstract}
Objective: Based on the study of some indicators of cellular and humoral immunity, evaluate the features of immunoreactivity in patients with psoriasis with concomitant pruritus. Materials and methods. Patients were examined with vulgar PS $(n=97)$, which were divided into 2 groups: group 1 - PS with pruritus ( $n=73$, mean age $40.0 \pm 1.5$ years), group 2 (comparison group) - PS without pruritus $(n=24$, mean age $41.5 \pm 2.7$ years). The cellular immunity indicators was carried out by flow cytofluorimetry. Phagocytic activity of peripheral blood neutrophils was studied microscopically by the absorption of latex particles. Concentrations of immunoglobulins, cytokines, circulating immune complexes in the blood serum were evaluated by the method of enzyme-linked immunosorbent assay. Statistica 6.0 was used for statistical analysis. Our studies allowed us to identify features of PS with concomitant pruritus: severe clinical course of the disease with damage to the musculoskeletal system, associated with selective deficiency of class M immunoglobulins and increased activity of phagocytic neutrophils.
\end{abstract}

Keywords: psoriasis; pruritus; psoriatic arthritis.

Цель исследования: на основании изучения некоторых показателей клеточного и гуморального звеньев иммунитета оценить особенности иммунореактивности у больных псориазом с сопутствующим кожным зудом. Материалы и методы. Обследованы больные вульгарным ПС $(n=97)$, которые были разделены на 2 группы: 1 группа - ПС с кожным зудом $(n=73$, средний возраст 40,0 $\pm 1,5$ лет), 2 группа (группа сравнения) - ПС без кожного зуда $(n=24$, средний возраст $41,5 \pm 2,7$ лет). Показатели клеточного звена иммунитета определяли методом проточной цитофлуориметрии. Фагоцитарную активность нейтрофилов периферической крови изучали микроскопически по поглощению латексных частиц. Концентрации иммуноглобулинов, цитокинов, циркулирующих иммунных комплексов в сыворотке крови оценивали методом твердофазного иммуноферментного анализа. Для статистического анализа применяли «Statistica 6.0». Проведенные нами исследования позволили выделить особенности ПС с сопутствующим кожным зудом: тяжелое клиническое течение заболевание с поражением опорно-двигательного аппарата, ассоциированное с селективным дефицитом иммуноглобулинов класса М и повышением активности фагоцитирующих нейтрофилов.

Ключевые слова: псориаз; кожный зуд; псориатический артрит.

Introduction. Psoriasis (PS) is an immunoassociated disease and often is accompanied by pruritus $[1,2]$. The interaction between the peripheral nervous system and the immune system is carried out through various types of skin nerve fibers that activate specific keratinocyte receptors [3]. The presence of pruritus in patients with PS may indicate violations of the immune system, which determines the relevance of the study. Based on the study of some indicators of cellular and humoral immunity, evaluate the features of immunoreactivity in patients with psoriasis with concomitant pruritus.

Materials and methods. Patients with PS were examined $(n=97)$ and divided into
2 groups: group $1-\mathrm{PS}$ with pruritus $(n=73$, mean age $40.0 \pm 1.5$ years), group 2 (comparison group) - PS without pruritus $(n=24$, mean age $41.5 \pm 2.7$ years). The indicators of cellular immunity were determined by flow cytofluorimetry. The concentration of immunoglobulins, cytokines, circulating immune complexes (CIC) in serum was assessed by enzyme-linked immunosorbent assay. Statistica 6.0 was used for statistical analysis. Data are presented as medians, 25 and 75 quartiles (Me, $\left.Q_{25}-Q_{75}\right)$. Differences were considered statistically significant at $p<0.05$.

Results and discussion. As a result of the research, it was noted that the presence of pruritus in PS patients is associated with a severe clini- 
cal course of the disease. Thus, the average value of the PASI index (Psoriasis Area and Severity Index - index of PS severity) in group 1 was $17.3(12.2 ; 20.1)$, in group $2-12.2(7.8 ; 18.4)$, $p_{1,2}=0.007$. Complaints of pain in the joints in $41(56.9 \%)$ cases are observed in group 1 and in $6(25 \%)$ in group $2, p_{1,2}=0.006$.

During the study, it was determined that in the group of patients with PS with concomitant pruritus the phagocytic number is higher and the concentration of IgM in serum is lower in comparison with the group of patients with PS without pruritus: $5.0(4.3 ; 5.5)$ and $4.0(3.8 ; 5.4), p_{1,2}=0.04$ and $0.6 \mathrm{~g} / 1(0.4 ; 1.1)$ relative to $1.1 \mathrm{~g} / 1(0.7 ; 1.3)$, $p_{1,2}=0.03$, respectively. An increase in the phagocytic number may indicate activation of the absorptive capacity of phagocytic neutrophils in PS with pruritus. A low serum IgM concentration may reflect a lack of humoral immunity as a result of a systemic psoriatic process in PS with concomitant pruritus. Previously conducted studies revealed differences in immunological parameters in patients with PS and psoriatic arthritis compared with the control group [4].

Conclusion. Studies have allowed to identify features of PS with concomitant pruritus: severe clinical course of the disease with damage to the musculoskeletal system, associated with selective deficiency of class $M$ immunoglobulins and increased activity of phagocytic neutrophils. Therefore, the presence of pruritus in patients with PS is associated with a change in immunological parameters, which confirms the close relationship of the nervous and immune systems and may be one of the markers of the progression of psoriatic disease.

\section{References}

1. Cantrell W. Psoriasis \& psoriatic therapies. Nurse Pract. 2017;42(7):35-39.

2. Smirnova SV, Smolnikova MV, Barilo AA. Clinical and anamnestic criteria of the progression of psoriasis. Russian Journal of Clinical Dermatology and Venereology. 2016;15(2):9-15. (In Russ.).

3. Dickison P, Swain G, Peek JJ, Smith SD. Itching for answers: Prevalence and severity of pruritus in psoriasis. Australas J Dermatol. 2018;59(3):206-209.

4. Barilo AA, Smirnova SV, Smolnikova MV. Immunological indicators of patients with psoriasis in different age groups. Cytokines and inflammation. 2017;16(3);31-22. (In Russ.).

5. Smirnova SV, Smolnikova MV, Barilo AA. The concentration of IL-4, IL-6, IL-10, TNF- $\alpha$ in the serum of patients with psoriasis and psoriatic arthritis. Cytokines and inflammation. 2015;14(4):9-12. (In Russ.). 